\title{
Experimental Study of Mineral Salts Concentration in
}

\section{Seawater}

Aroussia Jaouahdou Abid and Mohamed Jomaa Safi

Research Unit Mechanic-Energetic (URME), National Engineering School of Tunis, University of Tunis-Manar, Tunis 1002, Tunisia

\begin{abstract}
Mineral salts are of great importance on the regulation of different metabolic activities of living organisms. The well-functioning of the body depends on mineral salts. These salts, existing naturally in small quantity in our diverse diets (grains, legumes, fruit, tea, egg, etc.), are concentrated in seawater. In this paper, the indirect freezing is used as a concentration process to recover the most of salt minerals naturally present in seawater. Freezing is known as a purification process, but this paper recovers the brine instead of the formed ice. A 3.5\% salinity solution with an appropriate setup is used to recover the maximum of salt in the brine. The work aims to develop a process for freezing salt concentration on cold walls. The influence of operating parameters has highlighted the important role of the cooling ramp and stay time on the salt concentration produced.
\end{abstract}

Key words: Mineral salts, concentration, freezing, separation.

\section{Nomenclature and Abbreviation}

$\begin{array}{ll}V_{0}, T_{\text {fluide }} & \text { Initial volume (L) and temperature }\left({ }^{\circ} \mathrm{C}\right) \\ T_{i}, T_{f} & \text { Initial and final freezing temperature }\left({ }^{\circ} \mathrm{C}\right) \\ t_{\text {ramp }} & \text { Cooling ramp (h) } \\ t_{e x} & \text { Stay time (h) } \\ V_{g}, C_{g} & \begin{array}{l}\text { Volume }(\mathrm{L}) \text { and salinity }(\mathrm{g} / \mathrm{L}) \text { of ice } \\ \text { produced }\end{array} \\ V_{S}, C s & \begin{array}{l}\text { Volume }(\mathrm{L}) \text { and salinity }(\mathrm{g} / \mathrm{L}) \text { of non } \\ \text { solidified solution }\end{array} \\ R_{F}=\frac{V_{g}}{V_{S o l}} & \text { Freezing rate } \\ E=\left(1-\frac{C_{g} V_{g}}{C_{0} V_{0}}\right) \times 100 & \text { Separation efficiency }\end{array}$

\section{Introduction}

The mineral salts, which are important for the health and the growth of organism, are inorganic compounds present in both the plant and animal kingdoms. They participate to bones and teeth formation and the regulation of body fluids. Since no organism can produce mineral salts, they are introduced by diet. In humans, the amount of mineral salts represents about 5\% of body weight [1]. Mineral salts are naturally present in the seawater in different

Corresponding author: Aroussia Jaouahdou Abid, Ph.D., research fields: mass and heat transfer, fluid dynamics and phase separation. E-mail: aroussia.jaouahdou@enit.rnu.tn. concentrations, depending on the sampling characteristics. Table 1 presents salts concentration in $3.5 \%$ seawater [2].

To recover this need of salt, seawater presents an alternative solution. Freezing is a phase change process, consumes less energy than distillation, but is still not used enough at industrial scale [3]. In this paper, an indirect freezing process was used. Seawater is in permanent contact with a cold surface, on which crystallization starts and then made up an increasingly impure crystalline layer. The saturation of the brine must be perfectly controlled to maximize the recovered salts in the brine.

Temperature gradient generates a migratory movement of salts in the brine and the formation of a crystalline structure made of less saline water. This process is used in cleaning waste water, concentrating foods (juice, ice cream) or separating some pharmaceutical products sensitive to heat [4].

\section{Materials and Methods}

All experiments are carried out in a rectangular plexiglas tank of $23 \mathrm{~cm} \times 12 \mathrm{~cm} \times 12 \mathrm{~cm}$ inner dimensions. The upper face is fitted by an insulated 
Table 1 Mineral salts in $3.5 \%$ seawater.

\begin{tabular}{ll}
\hline Mineral salts & Concentration (g/L) \\
\hline Chloride $(\mathrm{Cl})$ & 19.35 \\
Sulfate $\left(\mathrm{SO}_{4}\right)$ & 2.71 \\
Bicarbonate $\left(\mathrm{HCO}_{3}\right)$ & 0.10 \\
Bromide $(\mathrm{Br})$ & 0.06 \\
Sodium (Na) & 10.78 \\
Magnesium (Mg) & 1.28 \\
Calcium (Ca) & 0.41 \\
Potassium (Mg) & 0.39 \\
\hline Bath
\end{tabular}

Fig. 1 Experimental setup.

Table 2 Operating conditions of experiments.

\begin{tabular}{llllll}
\hline $\mathrm{N}_{\text {exp }}$ & $T_{\text {fluide }}\left({ }^{\circ} \mathrm{C}\right)$ & $T_{i}\left({ }^{\circ} \mathrm{C}\right)$ & $T_{f}\left({ }^{\circ} \mathrm{C}\right)$ & $t_{\text {ram }}(\mathrm{h})$ & $t_{e x}(\mathrm{~h})$ \\
\hline 1 & 20 & -2 & -4 & 24 & 2 \\
2 & 22 & -2 & -5 & 24 & 2 \\
3 & 18 & -2 & -6 & 24 & 2 \\
4 & 20 & -2 & -7 & 24 & 2 \\
5 & 18 & -2 & -8 & 24 & 2 \\
6 & 20 & -2 & -10 & 24 & 2 \\
7 & 19 & -2 & -6 & 12 & 2 \\
8 & 18 & -2 & -6 & 18 & 2 \\
9 & 18 & -2 & -6 & 30 & 2 \\
10 & 19 & -2 & -8 & 12 & 2 \\
11 & 18 & -2 & -8 & 18 & 2 \\
12 & 18 & -2 & -8 & 30 & 2 \\
13 & 18 & -2 & -6 & 12 & 12 \\
14 & 18 & -2 & -8 & 12 & 12 \\
\hline
\end{tabular}

$\mathrm{N}_{\text {exp }}$ is the experiment number.

exchanger. Cold is produced by a Thermo Haake C35P cryostatic circulator (Fig. 1). The tank is filled by a seawater solution at $35 \mathrm{~g} / \mathrm{L}$ (seawater average concentration [5]). At $t=0 \mathrm{~s}$, the exchanger is cooled at $0{ }^{\circ} \mathrm{C}$ and the solution is introduced into the tank. A linear profile of temperature starting at $T_{i}$ to final temperature $T_{f}$ within $t_{\text {ram }}$ duration is applied. The solution is initially at $T_{\text {fluide }}$. After the establishment of $T_{f}$, the solution still remains during $t_{e x}$. At the end of the experiment, the authors recover not frozen solution of $V_{s}$ volume and salt concentration $C_{s}$.
The melting of the ice formed at the bottom of the tank gives the least concentrated solution of $V_{g}$ volume and $C_{g}$ concentration. Mineral salt recovered are presented by $V_{g}$ and $C_{s}$.

\section{Results and Discussion}

Most representative experiments and results are summarized in Tables 2 and 3.

Separation efficiency, expressed in terms of all intervening parameters in the separation process, and the rate of freezing of each experiment [6] are listed in Table 4. Rate of freezing shows the fraction crystallized at the end of the experiment.

Table 3 Results of salts concentration.

\begin{tabular}{lllll}
\hline $\mathrm{N}_{\text {exp }}$ & $V_{s}(\mathrm{~L})$ & $C_{s}(\mathrm{~g} / \mathrm{L})$ & $V_{g}(\mathrm{~L})$ & $C_{g}(\mathrm{~g} / \mathrm{L})$ \\
\hline 1 & 2.8 & 36 & 0.2 & 14 \\
2 & 2.2 & 43 & 0.8 & 12 \\
3 & 1.9 & 47 & 1.1 & 12 \\
4 & 1.9 & 43 & 1.1 & 16 \\
5 & 1.8 & 44.5 & 1.2 & 14 \\
6 & 1.2 & 71 & 1.8 & 10.5 \\
7 & 2.3 & 42 & 0.7 & 10 \\
8 & 2.1 & 45 & 0.9 & 11 \\
9 & 1.8 & 44 & 1.2 & 20 \\
10 & 1.8 & 55 & 1.2 & 12 \\
11 & 1.78 & 49 & 1.22 & 12 \\
12 & 1.5 & 50 & 1.5 & 19 \\
13 & 1.9 & 49 & 1.1 & 8 \\
14 & 1.6 & 56 & 1.4 & 11 \\
\hline
\end{tabular}

$\mathrm{N}_{\text {exp }}$ is the experiment number.

Table 4 Separation efficiency and freezing rate.

\begin{tabular}{lll}
\hline $\mathrm{N}_{\exp }$ & $E(\%)$ & $R_{F}(\%)$ \\
\hline 1 & 97.33 & 6.66 \\
2 & 90.4 & 28 \\
3 & 87.42 & 36.66 \\
4 & 83.23 & 36.66 \\
5 & 84 & 40 \\
6 & 82 & 60 \\
7 & 93.33 & 23.33 \\
8 & 90.57 & 30 \\
9 & 77.14 & 40 \\
10 & 86.28 & 40 \\
11 & 86.05 & 40.66 \\
12 & 72.85 & 50 \\
13 & 91.6 & 36.66 \\
14 & 85.33 & 46.66 \\
\hline$N_{\exp }$ is the experiment number.
\end{tabular}




\subsection{Freezing Temperature Effect}

Experiments 1-6 are carried out under the same conditions except the freezing temperature $T_{f}$ (Fig. 2).

It is noted well that even $T_{f}$ increase, the separation efficiency is better but the rate of freezing decreases. Freezing at $-8{ }^{\circ} \mathrm{C}$ gives the better concentration rate of mineral salts. Indeed, freezing at low temperature, give more crystalline lattice, but in the same time support trapping of salt in the ice lattice and then little salt concentration in the brine to be recuperated [7].

\subsection{Freezing Speed Effect}

The freezing speed is definite by temperature range on time range $(\Delta T / \Delta t)$. Experiments $3,7,8$ and 9 are carried out at the same temperature $\left(-6^{\circ} \mathrm{C}\right)$ and under the same conditions except the cooling speed, as shown in Table 5. Experiments 5, 10, 11 and 12 are carried out at $-8{ }^{\circ} \mathrm{C}$ and under the same conditions but for different cooling speed, as shown in Table 6.

Whatever the freezing temperature at $-6{ }^{\circ} \mathrm{C}$ or $-8{ }^{\circ} \mathrm{C}$, the separation efficiency and mineral salt concentration are similar. The separation efficiency increased with the freeze speed, and so we recover more salts in brine.

In this case, freezing quickly accelerates the advance of the solid/liquid interface that supports the convection in the solution. These motions are reinforced by the effect of gravity [8].

\subsection{Stay Time Effect}

Experiments 7 and 13 are carried out at $-6{ }^{\circ} \mathrm{C}$ under the same conditions except the different stay time ( $2 \mathrm{~h}$ and $12 \mathrm{~h}$, respectively). In the same way, experiments 10 and 13 are also carried out at $-8{ }^{\circ} \mathrm{C}$ under the same conditions except the different stay time ( $2 \mathrm{~h}$ and $12 \mathrm{~h}$, respectively). These four experiments confirm that when $T_{e x}$ increases, $R_{F}$ increases and consequently $E$ decreases. Freezing act in the solution makes it possible to concentrate more mineral salts in brine.

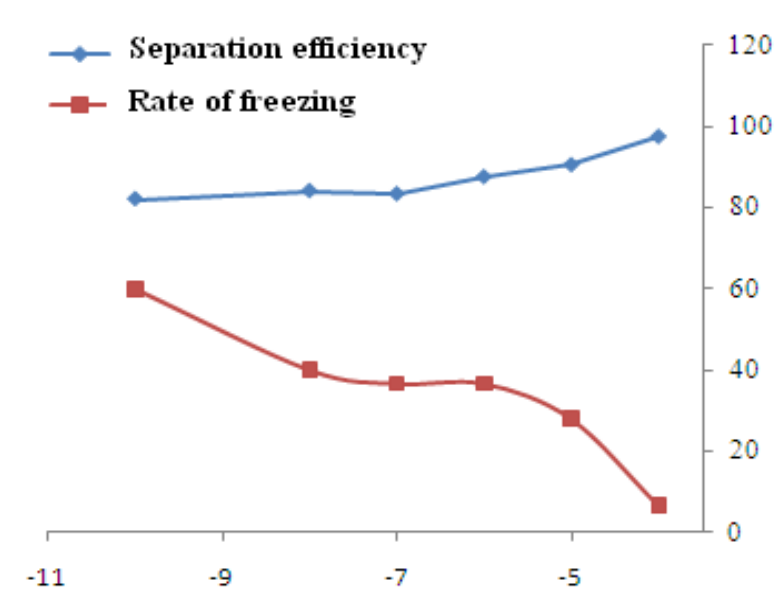

Fig. $2 E$ and $R_{F}$ versus freezing temperature.

Table 5 Freezing speed and separation efficiency at $T_{f}=$ $-6{ }^{\circ} \mathrm{C}$.

\begin{tabular}{lll}
\hline $\begin{array}{l}\text { Freezing speed } \\
\left({ }^{\circ} \mathrm{C} / \mathrm{h}\right)\end{array}$ & $E(\%)$ & $\begin{array}{l}\text { Mineral salt } \\
\text { concentration }(\mathrm{g} / \mathrm{L})\end{array}$ \\
\hline 0.33 & 93.33 & 47 \\
0.22 & 90.57 & 45 \\
0.16 & 87.42 & 44 \\
0.13 & 77.14 & 42 \\
\hline
\end{tabular}

Table 6 Freezing speed and separation efficiency at $T f=$ $-8{ }^{\circ} \mathrm{C}$.

\begin{tabular}{lll}
\hline $\begin{array}{l}\text { Freezing speed } \\
\left({ }^{\circ} \mathrm{C} / \mathrm{h}\right)\end{array}$ & $E(\%)$ & $\begin{array}{l}\text { Mineral salt } \\
\text { concentration }(\mathrm{g} / \mathrm{L})\end{array}$ \\
\hline 0.33 & 86.28 & 55 \\
0.22 & 86 & 50 \\
0.16 & 84 & 49 \\
0.13 & 72.5 & 44 \\
\hline
\end{tabular}

\subsection{Efficiency of Separation}

Experiment 14 represents the length stage of freezing with about $24 \mathrm{~h}$ between freezing and staying time. This freezing makes it possible to concentrate about $56 \mathrm{~g} / \mathrm{L}$ of mineral salts in $1.6 \mathrm{~L}$ of solution. The freezing from above, under certain conditions, can be a good process to concentrate mineral salts or other component.

\section{Conclusions}

This study shows the effect of different parameter, such as freezing temperature and speed in the concentration of mineral salts in brine. The increasing of salt concentration creates a dendritic lattice due to 
the concentration gradient. Since the cooling is from above, the thermal gradient is in opposite direction of the gravity and the mass gradient. This makes the flow unstable. Convection, which is known to be the driving force of the flow in such case, is the result of the migration of salts in the brine. Freezing is a separation process that can be used in mineral salts concentration, food concentration and pharmaceutical treatment solutions that do not tolerate heat. A compromise between the freezing configuration-the freezing temperature and speed is to be established.

\section{References}

[1] Soetan, K. O., Olaiya, C. O., and Oyewole, O. E. 2010. "The Importance of Mineral Elements for Humans, Domestic Animals and Plants: A Review." African Journal of Food Science 4 (5): 200-22.

[2] UNESCO. 2006. Water: A Shared Responsibility. 2nd United Nation Report on the Development of Water
Resources Value.

[3] Jaouahdou, A., Safi, M. J., and Muhr, H. 2010. “Solidification of Binary Alloy: Freezing from below.” In Proceeding of the Fifth International Congress on Renewable Energy and Environment (CERE), 234-41.

[4] Baker, R. A. 1970. "Trace Organic Contaminant Concentration by Freezing: Part III, Ice Washing.” Water Research 3 (9): 717-30.

[5] Wiegandt, H. F., Harriott, P., and Leinroth, J. P. 1968. Desalting of Seawater by Freezing. R \& D Report 376, Office of Saline Water, US Department of Commerce.

[6] Jaccard, C., and Levi, L. 1961. "Segregation of Impurities in the Ice." Journal of Applied Mathematics and Physic 12 (1): 70-6.

[7] Nakagawa, K., Hottot, A., Vessot, S., and Andrieu, J. 2007. "Modeling of Freezing Step during Freeze-Drying of Pharmaceutical Proteins in Vials: Influence of Nucleation Temperature.” American Institute of Chemical Engineers 53 (5): 1362-72.

[8] Caldwell, D. R. 1974. "Experimental Studies on the Onset of Thermohaline Convection.” Journal of Fluid Mechanics 64: 347-67. 